\title{
ANALISIS RESOURCE LEVELING SUMBER DAYA ALAT MENGGUNAKAN METODE BURGESS
}

\author{
Candra Yuliana $^{* 1}$, Retna Hapsari Kartadipura² ${ }^{2}$ an Satria Wijaya ${ }^{3}$ \\ ${ }^{1}$ Dosen, Program Studi Teknik Sipil, Fakultas Teknik, Universitas Lambung Mangkurat \\ ${ }^{2}$ Dosen, Program Studi Teknik Sipil, Fakultas Teknik, Universitas Lambung Mangkurat \\ ${ }^{3}$ Mahasiswa, Program Studi Teknik Sipil, Fakultas Teknik, Universitas Lambung \\ Mangkurat \\ Email: candrayuliana@ulm.ac.id
}

\begin{abstract}
ABSTRAK
Dalam mengalokasikan sumber daya diperlukan logika saling ketergantungan antar kegiatan dalam suatu proyek konstruksi. Semakin banyak kegiatan atau pekerjaan yang terdapat dalam suatu proyek maka semakin rumit pula pengalokasian sumber daya tersebut. Karena kerumitan tersebut, maka alokasi sumber daya yang direncanakan tidak terdistribusi secara ideal sehingga mengakibatkan alokasi sumber daya yang bersifat tidak tetap. Penelitian dilakukan pada dua proyek jalan yaitu pada proyek Jalan Kiram-Simpang 3 Tahura-Mandiangin dan Jalan Gunung Kupang-Kiram-Tambang Ulang, dengan pembahasan khusus pada sumber daya alat. Pemanfaatan alat berat pada suatu proyek konstruksi dapat memberi insentif pada efisiensi dan efektifitas pada tahap pelaksanaan maupun hasil yang dicapai maka diperlukan upaya penelitian dengan menerapkan perataan sumber daya (resource leveling) peralatan. Tujuan penelitian ini adalah membuat penjadwalan dan alokasi alat setelah dilakukan resource leveling, menganalisa perbandingan pada biaya dan waktu alokasi alat sebelum dan setelah resource leveling. Metode analisis menggunakan metode burgess terhadap dua proyek sekaligus. Setelah dilakukan resource leveling pada aktifitas-aktifitas non kritis, penggunaan alat dan biaya langsung perminggu lebih stabil atau hampir rata. Hasilnya maka perlu dilakukan penundaan sebanyak 4 minggu pada pekerjaan pasangan batu dengan mortar pada proyek 2 , dan penundaan sebanyak 7 minggu pada pekerjaan pasangan batu dengan mortar pada proyek 1 .
\end{abstract}

Kata kunci: alokasi sumber daya alat, burgess, resources leveling.

\section{PENDAHULUAN}

Pelaksanaan suatu proyek umumnya terdiri dari beberapa atau banyak kegiatan yang memerlukan waktu, dana, dan sumber-sumber daya. Sumber daya yang dimaksud dapat berupa tenaga manusia, alat dan bahan [1].

Tahura merupakan destinasi wisata alam yang dimiliki Provinsi Kalsel terletak di Desa Mandiangin Kecamatan Karang Intan Kabupaten Banjar. Demi kenyamanan dan keamanan para wisatawan, maka akses jalan di daerah Mandiangin dan Gunung Kupang dibenahi dengan diadakannya peningkatan infrastruktur Jalan Kiram Simpang 3 Tahura Mandiangin dan Jalan Gunung Kupang Kiram Tambang Ulang oleh Dinas PekerjaanUmum Provinsi Kalimantan Selatan.

Dalam tahapan pelaksanaan proyek tersebut ada beberapa pekerja yang tidak bekerja dan alat yang tidak digunakan pada jam kerja, seperti alat Excavator PC. Selain itu, sering terjadi penggunaan alat yang menumpuk pada waktu tertentu seperti alat Concrete Mixer. Hal tersebut berdampak pada alokasi sumber daya peralatannya tidak merata. Peralatan merupakan salah satu sumber daya terpenting yang dapat mendukung tercapainya suatu tujuan yang diinginkan. Peralatan konstruksi yang dimaksud adalah alat/peralatan yang diperlukan untuk melakukan pekerjaan konstruksi secara mekanis. Ini dapat berupa grader, truk, pengeruk tanah, kompresor udara, dll. Artinya pemanfaatan alat berat pada suatu proyek konstruksi dapat memberi insentif pada efisiensi dan efektifitas pada tahap pelaksanaan maupun hasil yang dicapai. 
Melihat latar belakang tersebut dimana dalam proyek Jalan Kiram Simpang 3 Tahura Mandiangin dan Jalan Gunung Kupang Kiram Tambang Ulang untuk mendapatkan alokasi dan penggunaan peralatan proyek yang optimal diperlukan upaya penelitian dengan menerapkan perataan sumber daya alat menggunakan metode burgess terhadap dua proyek sekaligus.

Isi jurnal meliputi Pendahuluan, Tinjauan Pustaka, Metodologi Penelitian, Hasil dan Pembahasan, Kesimpulan dan Saran, Daftar Pustaka.

\section{TINJAUAN PUSTAKA}

\subsection{Penjadwalan}

Penjadwalan merupakan pengalokasian waktu yang tersedia untuk melaksanakan masing-masing pekerjaan dalam rangka menyelesaikan suatu proyek hingga tercapai hasil optimal dengan mempertimbangkan keterbatasan-keterbatasan yang ada [2]. Penjadwalan proyek merupakan proses perhitungan waktu penyelesaian proyek yang telah ditentukan, dengan mempertimbangkan batasan-batasan yang mempengaruhi pelaksanaan kegiatan tersebut. Jadwal adalah penjelasan perencanaan proyek menjadi urutan kegiatan yang sistematis untuk mencapai satu sasaran [3]. Pendekatan yang dipakai adalah jaringan kerja yang menggambarkan suatu grafik hubungan urutan pekerjaan proyek. Pekerjaan mana yang harus didahulukan dari pekerjaan yang lain harus didentifikasikan secara jelas dalam kaitannya dengan waktu pelaksanaan pekerjaan.

Menurut PMBOK [3], fungsi dari penjadwalan yaitu sebagai pedoman dan pengendalian untuk pelaksanaan kegiatan agar sesuai rencana, sebagai dasar penentuan progress payment, penyusunan cash flow proyek dan pembuatan strategi pendanaan proyek. Memberikan pedoman kepada sub-ordinate units mengenai batas-batas waktu bagi mulainya dan berakhirnya tugas masing-masing. Dapat dipakai untuk mengevaluasi dampak akibat adanya perubahan-perubahan pelaksanaan proyek

Penjadwalan menentukan kapan aktivitas itu dimulai, ditunda dan diselesaikan, sehingga pembiayaan dan pemakaian sumber daya bisa disesuaikan waktunya menurut kebutuhan yang telah ditentukan. Untuk menyelenggarakan proyek, salah satu sumber daya yang menjadi faktor penentu keberhasilan adalah tenaga kerja [4].

Dalam sebuah proyek konstruksi, penjadwalan memainkan peranan yang signifikan dalam menentukan keberhasilan proyek secara keseluruhan. Dengan penjadwalan yang baik, aktivitas-aktivitas dalam sebuah proyek akan berjalan dengan lancar, misalnya mobilisasi dan demobilisasi tenaga kerja dan peralatan dapat terlaksana dalam kerangka waktu yang tepat untuk menghindari terjadinya penundaan dan pemborosan. Sebagai hasil akhir akan diperoleh sebuah kombinasi yang optimal antara waktu pelaksanaan, biaya yang dikeluarkan, dan kualitas yang dihasilkan. Untuk merencanakan secara grafis dari aktivitas pelaksanaan pekerjaan konstruksi dikenal beberapa diagram diantaranya Diagram Balok, Diagram Panah, dan Diagram Precedence (PDM).

Diagram batang adalah untuk mengidentifikasi unsur waktu dan urutan dalam perencanaan suatu kegiatan yang terdiri dari waktu selesai dan waktu pelaporan. Network analysis sebenarnya adalah perbaikan dari metode diagram batang. Metode tersebut menyajikan secara jelas hubungan ketergantungan antara bagian kegiatan dengan kegiatan lain, dan kegiatan yang tidak perlu tergesa-gesa. Metode network analisis tersebut mengalami penyempurnaan secara bertahap, yaitu PERT, CPM, PDM dan terakhir penjadwalan dengan komputer [5] [6].

PDM merupakan salah satu teknik penjadwalan yang termasuk dalam teknik penjadwalan Network Planning atau Rencana Jaringan Kerja. Berbeda dengan Activity on arrow (AOA) yang menitikberatkan kegiatan pada anak panah, PDM menitikberatkan kegiatan pada node sehingga kadang disebut juga Activity on Node (AON) [7]. Precedence Diagramming Method memberikan cara yang lebih mudah untuk menjelaskan hubungan logis antar kegiatan konstruksi yang kompleks, khususnya jika terjadi kegiatan-kegiatan yang terjadi bersamaan. PDM juga cenderung lebih kecil dalam ukuran pembuatannya. Hal yang paling utama dalam pembuatan PDM adalah, bahwa PDM lebih cepat dalam persiapan pembuatannya sehingga penjadwal tidak membutuhkan banyak waktu dalam mempersiapkan jadwal PDM. Selain itu, PDM juga menghapus kebutuhan akan kegiatan dummy dan detail tambahan untuk menunjukan 
tumpeng tindih antara kegiatan [8].

\subsection{Metode Burgess}

Metode Burgess adalah metode dengan menentukan jumlah nilai kuadrat (Z) dari tenaga kerja yang akan dianalisis. Semakin kecil nilai $\mathrm{Z}$ maka fluktuasi yang timbul pada kebutuhan sumber daya tenaga kerja akan semakin kecil. Dengan mengetahui alokasi jumlah kebutuhan sumber daya tenaga kerja, dapat dihitung besar nilai $\mathrm{Z}$ dengan rumus [9]:

dimana:

$$
Z=\sum_{1}^{T} y_{i}^{2}
$$

$\mathrm{Z}=$ jumlah kuadrat suatu periode waktu

$\mathrm{T}=$ durasi proyek

$\mathrm{y}_{\mathrm{i}}=$ jumlah dari sumber daya yang diperlukan dari setiap kegiatan per unit waktu

Perataan sumber daya tenaga kerja pada metode Burgess hanya terjadi pada kegiatan non kritis. Pada langkah ini akan dilakukan system reserve late start dimana kegiatan non kritis dengan waktu mulai paling akhir (late start/LS) akan ditempatkan pada tempat pertama. Setelah itu, hitung jumlah kuadrat setelah dilakukan penundaan kegiatan untuk setiap unit waktu sesuai dengan jumlah float kegiatan tersebut. Perhitungan ini dilakukan secara berulang-ulang hingga setiap kegiatan non kritis dengan system reserve late start yang telah dianalisis semua [10]. Adapun prosedur metode Burgess adalah sebagai berikut:

1. Buat daftar kegiatan proyek sesuai urutan prioritas. Tambahkan ini daftar nilai durasi, mulai awal, dan float untuk masing-masing aktivitas.

2. Dimulai dengan aktivitas terakhir, jadwalkan periode demi periode berikan jumlah kuadrat terendah dari persyaratan sumber daya untuk masing-masing satuan waktu. Jika lebih dari satu jadwal yang memberikan jumlah total kotak yang sama, lalu jadwalkan aktivitas selambat mungkin untuk mendapatkan float sebanyak mungkin dalam semua kegiatan sebelumnya.

3. Tahan aktivitas terakhir, ulangi langkah $2 \mathrm{di}$ sebelah aktivitas terakhir dalam jaringan, memanfaatkan setiap float itu mungkin telah tersedia untuk itu dengan penjadwalan ulang pada langkah 2.

4. Lanjutkan langkah 3 hingga aktivitas pertama dalam daftar telah dipertimbangkan.

5. Lakukan siklus penjadwalan tambahan dengan mengulangi langkah 2 melalui 4 sampai tidak ada pengurangan lebih lanjut dalam jumlah total kuadrat persyaratan sumber daya dimungkinkan.

6. Ulangi langkah 1 sampai 5 pada urutan kegiatan yang berbeda.

7. Pilih jadwal terbaik dari yang diperoleh di langkah 5 dan 6.

8. Buat penyesuaian akhir untuk jadwal yang dipilih pada langkah 7, dengan mempertimbangkan faktor-faktor yang tidak dipertimbangkan dalam dasar prosedur penjadwalan

\subsection{Alokasi Sumber Daya}

Perencanaan waktu proyek dan keberhasilan pelaksanaanya ditentukan oleh perencanaan alokasi ketersediaan (resources) proyek. Perencanaan tersebut meliputi perencanaan penyediaan dan alokasi alat (SDM), perencanaan penyediaan material, perencanaan penyediaan peralatan, perencanaan penyediaan dan alokasi keuangan [11].

Dalam penelitian ini secara lebih khusus pembahasan diarahkan pada perencanaan penyediaan dan alokasi alat. Dalam suatu proyek, alat yang digunakan memiliki porsi biaya yang terbesar. Oleh karena itu, sudah merupakan keharusan bagi seseorang pimpinan atau manajer proyek untuk memerhatikan dengan cermat hal tersebut agar tidak terjadi pemborosan. Contoh berikut (Gambar 1) adalah grafik yang kurang baik.

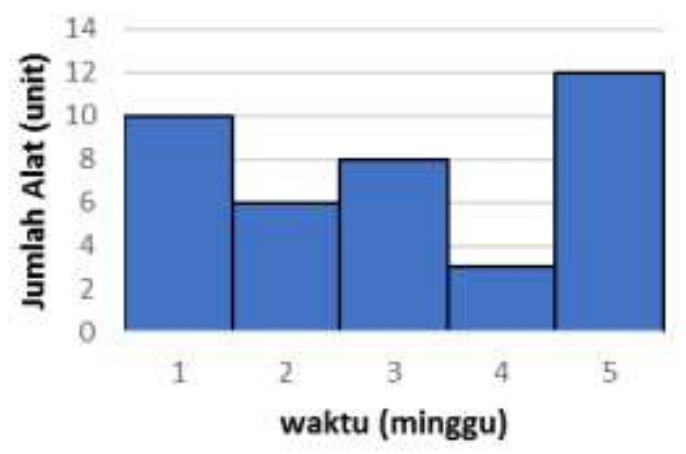

Gambar 1. Grafik yang tidak ideal

Dikatakan tidak baik karena pada periode pertama kebutuhan akan alatnya besar yaitu 10 alat. Namun, pada periode kedua, kebutuhannya sedikit yaitu 6 . Dengan demikian, ada kelebihan sebanyak 4 alat. Untuk menghindari pemborosan biaya tenaga, 
kelebihan pada periode pertama diberhentikan karena tidak mungkin tidak bekerja tapi tetap dibayar. Namun pada periode ketiga kembali kebutuhan tenaganya meningkat. Kondisi yang naik turun atau fluktuasi tersebut tidak menguntungkan. Dengan kondisi demikian, perusahaan hanya memiliki dua pilihan, yaitu memindahkan alat kelebihan tersebut ke proyek lain yang membutuhkannya atau menanggung kerugian karena tetap membayar alat tersebut selama tanpa tugas. Grafik yang terbaik adalah apabila jumlah alat meningkat dari awal proyek atau rata atau banyak, kemudian sedikit demi sedikit kemudian meningkat, dan kembali sedikit sampai akhir proyek, seperti grafik ideal yang terlihat pada Gambar 2.

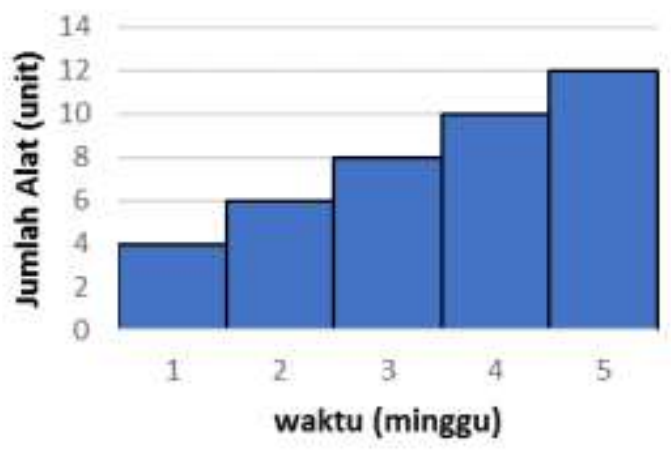

Gambar 2. Grafik yang ideal

\section{METODOLOGI PENELITIAN}

\subsection{Pengumpulan Data}

Data primer meliputi kondisi lapangan, jumlah peralatan, alokasi pekerjaan alat dilapangan, susunan peralatan dilapangan, durasi peralatan dilapangan, kendala peralatan dilapangan dan hal-hal yang menunjang penelitian langsung yang terdapat dilapangan. Data primer tersebut didapat dengan cara wawancara kepada pihak proyek yaitu site manager (kontraktor) dan pengawas lapangan. Data sekunder diperoleh dari pihak proyek Jalan Kiram Simpang 3 Tahura Mandiangin dan Jalan Gunung Kupang Kiram Tambang
Ulang Banjarbaru Kalimantan Selatan yang berupa data umum proyek, studi literatur, time schedule, volume item peralatan, durasi pekerjaan rencana, gambar rencana proyek, serta alat yang terdapat pada proyek konstruksi.

\subsection{Variabel Penelitian}

Variabel bebas dalam penelitian ini adalah work package (paket pekerjaan), jenis alat berat, time schedule, durasi, volume dan harga satuan pekerjaan. Variabel penelitian ini diukur berdasarkan data proyek di lapangan. Sedangkan variabel terikatnya adalah alokasi penjadwalan alat dan biaya per periode.

\subsection{Analisis Data}

Tahapan analisis pengolahan data dalam penelitian ini meliputi:

1. Membuat WBS (Work Breakdown Structure) atau memecahkan tiap proses pekerjaan menjadi lebih detail.

2. Melakukan penjadwalan ulang dengan PDM agar dapat melihat pekerjaan mana yang kritis dan non kritis.

3. Perhitungan menggunakan metode Burgess dari peralatan yang akan dianalisis dengan cara trial and error.

4. Membuat PDM berdasarkan data peralatan hasil resource leveling yang elah untuk mendapatkan histogram yang baru serta grafik yang paling ideal.

5. Menghitung biaya dan waktu penggunaan alat proyek sebelum dan sesudah diterapkan resource leveling.

\section{HASIL DAN PEMBAHASAN}

\subsection{Penjadwalan dengan PDM}

Pada setiap proyek dibuat WBS sehingga didapatkan lingkup pekerjaan yang lebih detail, selanjutnya dibuat penjadwalan dengan metode PDM terlihat pada Gambar 3 dan Gambar 4. 

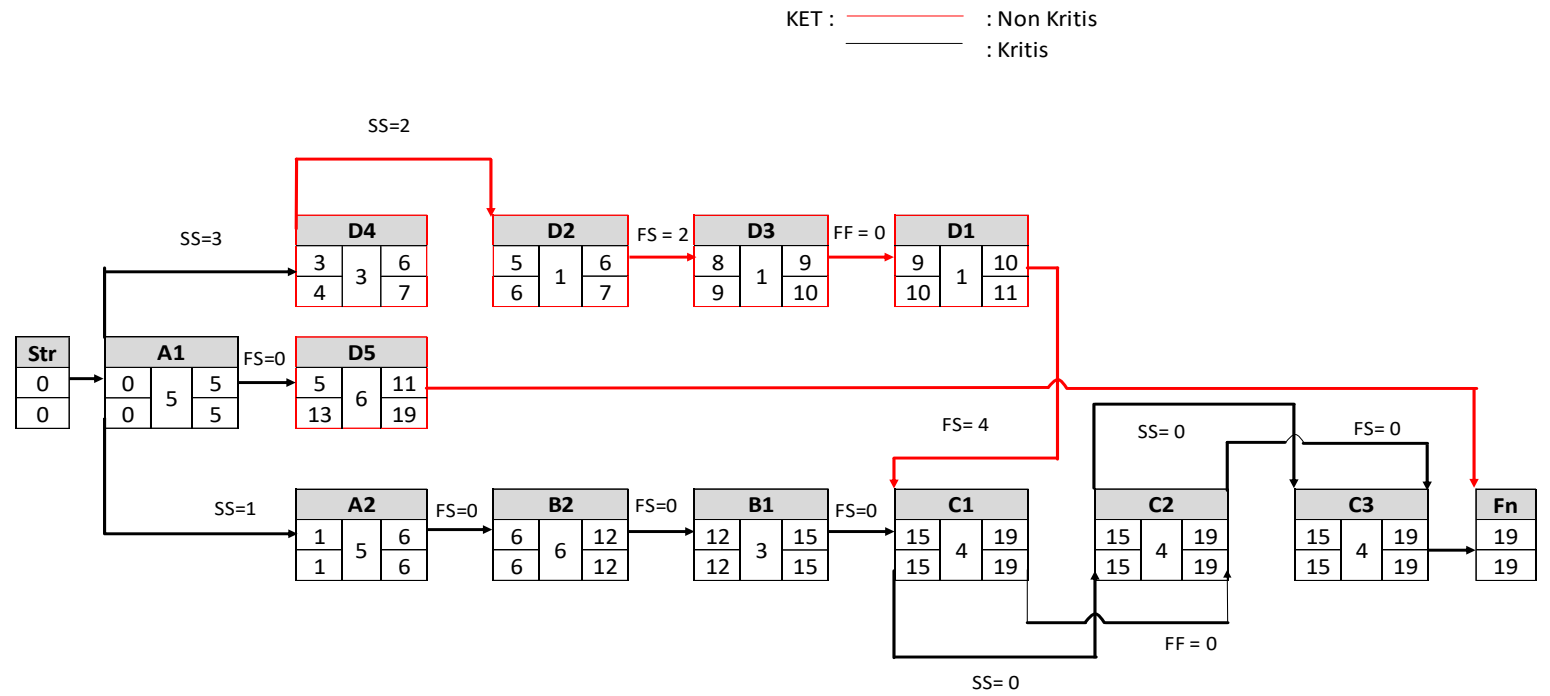

Gambar 3. Penjadwalan dengan PDM Proyek 1

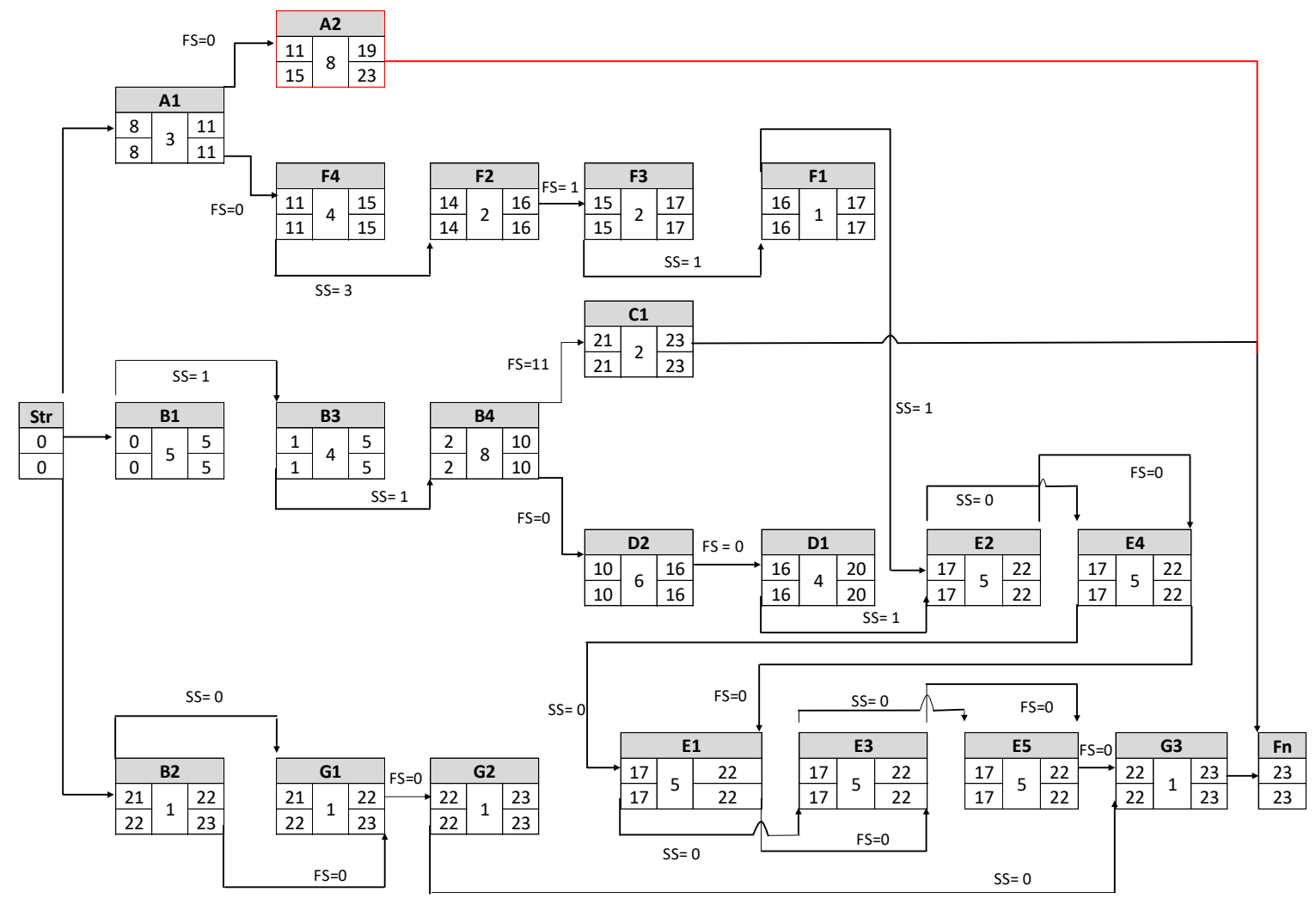

Gambar 4. Penjadwalan dengan PDM proyek 2

\subsection{Proses Resource Leveling Alat dengan Metode Burgess}

Penjadwalan dengan PDM (Gambar 3 dan Gambar 4) untuk masing-masing proyek kemudian digabung menjadi satu jadwal dengan menggunakan metode bar chart. Dari penjadwalan bar chart tersebut kemudian dilakukan proses leveling. Proses leveling alat dengan metode burgess dilakukan dengan sistem trial and error untuk mendapatkan jumlah penggunaan alat $\mathrm{Z}$ yang paling minimum, dimana proses leveling hanya dilakukan pada item pekerjaan non kritis pada kedua proyek yaitu pada proyek 1 bagian pekerjaan beton mutu sedang, beton mutu rendah, baja tulangan, pondasi cerucuk, penyediaan dan pemasangan, pada proyek dua pada bagian pengerjaan pasangan batu dengan 
mortar, dan lapis pondasi agregat kelas S.

Setelah dilakukan sistem penundaan dan proses leveling, berdasarkan jumlah float, dengan cara trial and error sebanyak 90 kali didapatkan jumlah kuadrat yang paling minimum dan paling ideal, yaitu:

a. penundaan pada pekerjaan pasangan batu dengan mortar pada proyek 2 sebanyak 4 minggu dan pada proyek 1 sebanyak 5 minggu (pada iterasi ke 59)

b. penundaan pada pekerjaan pasangan batu dengan mortar pada proyek 2 sebanyak 4 minggu dan pada proyek 1 sebanyak 6 minggu (pada iterasi ke 69) c. penundaan pada pekerjaan pasangan batu dengan mortar pada proyek 2 sebanyak 4 minggu dan pada proyek 1 sebanyak 7 minggu (pada iterasi ke 79)

Hasil penjadwalan setelah leveling, hanya pada penggunaan alat concrete mixer yang mengalami perubahan setelah dilakukan pengunduran pekerjaan pasangan batu dengan mortar sedangkan pada penggunaan alat yang lain adalah sama. Sebelum dilakukan pengunduran pekerjaan nilai $\mathrm{Z}$ pada penggunaan alat Concrete Mixer adalah 29 (Gambar 5). Sedangkan setelah dilakukan pengunduran nilai $\mathrm{Z}$ adalah 23 (Gambar 6).

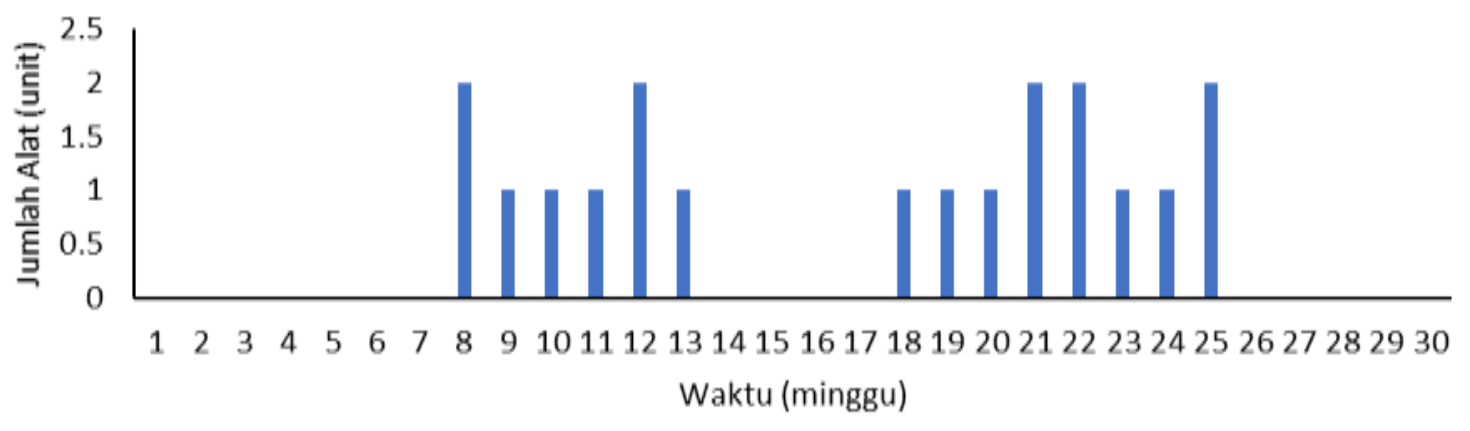

Gambar 5. Histogram penggunaan concrete mixer sebelum leveling

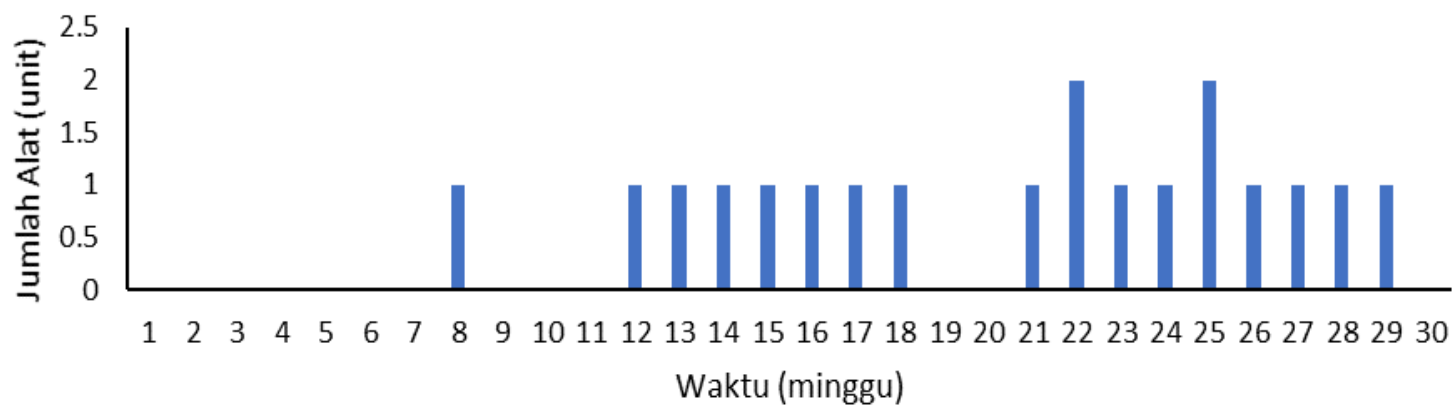

Gambar 6. Histogram penggunaan concrete mixer iterasi ke 79

Tabel 5. Biaya langsung perminggu sebelum resource levelling

\begin{tabular}{|l|c|c|c|c|r|}
\hline Periode & $\begin{array}{c}\text { Biaya Langsung } \\
(\mathrm{Rp})\end{array}$ & Periode & $\begin{array}{c}\text { Biaya Langsung } \\
(\mathrm{Rp})\end{array}$ & Periode & $\begin{array}{c}\text { Biaya Langsung } \\
(\mathrm{Rp})\end{array}$ \\
\hline Minggu ke 1 & - & Minggu ke 12 & $496.753 .998,62$ & Minggu ke 23 & $682.643 .522,34$ \\
\hline Minggu ke 2 & - & Minggu ke 13 & $373.974 .704,55$ & Minggu ke 24 & $832.890 .987,67$ \\
\hline Minggu ke 3 & $8.571 .406,85$ & Minggu ke 14 & $315.579 .611,22$ & Minggu ke 25 & $1.366 .861 .954,55$ \\
\hline Minggu ke 4 & $12.846 .200,13$ & Minggu ke 15 & $297.419 .166,98$ & Minggu ke 26 & $990.709 .471,80$ \\
\hline Minggu ke 5 & $12.846 .200,13$ & Minggu ke 16 & $297.419 .166,98$ & Minggu ke 27 & $990.709 .471,80$ \\
\hline Minggu ke 6 & $14.126 .504,13$ & Minggu ke 17 & $297.419 .166,98$ & Minggu ke 28 & $497.823 .606,96$ \\
\hline Minggu ke 7 & $14.126 .504,13$ & Minggu ke 18 & $831.220 .620,51$ & Minggu ke 29 & $746.311 .316,17$ \\
\hline Minggu ke 8 & $90.780 .077,79$ & Minggu ke 19 & $831.220 .620,51$ & Minggu ke 30 & $287.480 .890,45$ \\
\hline Minggu ke 9 & $385.348 .851,53$ & Minggu ke 20 & $831.220 .620,51$ & Minggu ke 31 & - \\
\hline Minggu ke 10 & $387.416 .376,15$ & Minggu ke 21 & $1.113 .326 .878,37$ & Minggu ke 32 & - \\
\hline Minggu ke 11 & $542.613 .861,05$ & Minggu ke 22 & $964.749 .780,20$ & Total & $14 / 514.411 .539,03$ \\
\hline
\end{tabular}


Tabel 6. Biaya langsung perminggu setelah resource leveling

\begin{tabular}{|l|r|l|r|l|r|}
\hline Periode & $\begin{array}{c}\text { Biaya Langsung } \\
(\mathrm{Rp})\end{array}$ & \multicolumn{1}{|c|}{ Periode } & $\begin{array}{c}\text { Biaya Langsung } \\
(\mathrm{Rp})\end{array}$ & Periode & $\begin{array}{c}\text { Biaya Langsung } \\
(\mathrm{Rp})\end{array}$ \\
\hline Minggu ke 1 & - & Minggu ke 12 & $329.021 .282,82$ & Minggu ke 23 & $682.643 .522,34$ \\
\hline Minggu ke 2 & - & Minggu ke 13 & $484.218 .767,72$ & Minggu ke 24 & $832.890 .987,67$ \\
\hline Minggu ke 3 & $8.571 .406,85$ & Minggu ke 14 & $315.579 .611,22$ & Minggu ke 25 & $1.366 .861 .954,55$ \\
\hline Minggu ke 4 & $12.846 .200,13$ & Minggu ke 15 & $355.814 .260,31$ & Minggu ke 26 & $1.299 .869 .780,20$ \\
\hline Minggu ke 5 & $12.846 .200,13$ & Minggu ke 16 & $355.814 .260,31$ & Minggu ke 27 & $1.299 .869 .780,20$ \\
\hline Minggu ke 6 & $14.126 .504,13$ & Minggu ke 17 & $355.814 .260,31$ & Minggu ke 28 & $806.983 .915,36$ \\
\hline Minggu ke 7 & $14.126 .504,13$ & Minggu ke 18 & $580.455 .405,44$ & Minggu ke 29 & $1.055 .471 .624,57$ \\
\hline Minggu ke 8 & $32.384 .984,46$ & Minggu ke 19 & $580.455 .405,44$ & Minggu ke 30 & $287.480 .890,45$ \\
\hline Minggu ke 9 & $326.953 .758,20$ & Minggu ke 20 & $580.455 .405,44$ & Minggu ke 31 & - \\
\hline Minggu ke 10 & $387.416 .376,15$ & Minggu ke 21 & $804.166 .569,97$ & Minggu ke 32 & - \\
\hline Minggu ke 11 & $542.613 .861,05$ & Minggu ke 22 & $964.749 .780,20$ & Total & $14 / 514.411 .539,03$ \\
\hline
\end{tabular}

\subsection{Perbandingan Biaya Sebelum dan Sesudah Resources Leveling}

Harga satuan pekerjaan terdiri dari biaya langsung dan overhead serta profit. Maka Biaya langsung adalah selisih dari harga satuan pekerjaan dengan overhead dan profit. Profit dan overhead sebesar $15 \%$ dari harga satuan pekerjaan, sehingga dapat dihitung biaya langsung perminggu pada proyek tersebut dengan mengurangkan $15 \%$ harga satuan. Kemudian dihitung biaya langsung perminggu dengan mengalikan biaya langsung persatuan pekerjaan terhadap volume yang dikerjakan pada minggu tersebut yang telah diketahui di time schedule.

Terlihat pada Tabel 1 dan Tabel 2 perbandingan biaya langsung sebelum dan sesudah dilakukan resource leveling. Perbedaan biaya langsung hanya terjadi pada minggu ke- 8 sampai dengan minggu ke-21. Diantara 3 kemungkinan penundaan dan kondisi sebelum resource leveling maka yang paling ideal yaitu pada kondisi penundaan pasangan batu dengan mortar selama 4 minggu pada proyek 2 dan 7 minggu pada proyek 1 (iterasi 79). Biaya langsung pada kondisi tersebut stabil. Biaya langsung pada minggu ke 8 sampai minggu ke-21 hanya terjadi satu kali penurunan biaya, selanjutnya biaya naik secara stabil. Berbeda dengan kondisi yang lain, terjadi naik dan turun biaya langsung pada periode tersebut.

\section{KESIMPULAN}

1. Pada penjadwalan gabungan (sebelum resource leveling) didapat penggunaan alat pada proyek 1 (Jalan Kiram Simpang 3 Tahura Mandiangin) selama 19 minggu dengan aktivitas non kritis sebanyak 5 item pekerjaan yakni pada pekerjaan Beton mutu sedang; dengan f'c $=20 \mathrm{MPa}$, Beton mutu rendah dengan $\mathrm{fc}=10 \mathrm{MPa}$, Baja tulangan U24 polos, Pondasi Cerucuk, Penyediaan dan Pemasangan, serta pekerjaan Pasangan batu dengan Mortar. Sedangkan pada proyek 2 (Jalan Gunung Kupang Kiram Tambang Ulang Banjarbaru Kalimantan Selatan) selama 23 minggu dengan aktivitas non-kritis sebanyak 1 item pekerjaan yaitu pekerjaan Pasangan batu dengan Mortar.

2. Setelah dilakukan resource leveling pada aktifitas non kritis (penjadwalan gabungan kedua proyek), didapatkan 3 kondisi dimana nilai dengan nilai $\mathrm{Z}$ minimum, yaitu:

a. penundaan pada pekerjaan pasangan batu dengan mortar pada proyek 2 sebanyak 4 minggu dan pada proyek 1 sebanyak 5 minggu (pada iterasi ke 59),

b. penundaan pada pekerjaan pasangan batu dengan mortar pada proyek 2 sebanyak 4 minggu dan pada proyek 1 sebanyak 6 minggu (pada iterasi ke 69),

c. penundaan pada pekerjaan pasangan batu dengan mortar pada proyek 2 sebanyak 4 minggu dan pada proyek 1 sebanyak 7 minggu (pada iterasi ke 79).

3. Setelah resource leveling penggunaan alat dan biaya langsung perminggu lebih stabil. Dimana yang paling ideal dan stabil penggunaan alat dan biaya langsungnya adalah pada kondisi dilakukan penundaan pada pekerjaan pasangan batu dengan mortar sebanyak 4 minggu pada proyek 2 , dan penundaan sebanyak 7 minggu pada proyek 1 . 


\section{DAFTAR PUSTAKA}

[1] Nugraha, P., Ishak Nathan, R. Sutjipto., Manajemen Proyek Konstruksi 2, Kartika Yudha: Surabaya, 1986.

[2] Husen, A., Manajemen Proyek Perencanaan, Penjadwalan \& Pengendalian Poyek, CV. Andi Offset: Yogyakarta, 2009.

[3] Soeharto, Iman., Manajemen Proyek: Dari Konseptual Sampai Operasional, Erlangga: Jakarta, 1997.

[4] Mertha Jaya, N., Diah Parami Dewi, A.A., Analisa Penjadwalan Proyek Menggunakan Rangked Positional Weight Method (Studi Kasus: Proyek Pembangunan Pasar Mumbul di Kabupaten Buleleng), Jurnal Ilmiah Teknik Sipil, Vol. 11 No. 2, Juli, 2007: pp.100 - 108.

[5] Kerzner, H., Project Management for Executives, Van Nostrand Reinhold Company, 1982.

[6] Siswojo, Pokok-pokok Project Management
PERT dan CPM, Erlangga: Jakarta, 1981.

[7] Callahan M. T., Quachenbush D. G., Rowings J. E., Construction Project Schedulling, McGraw-Hill Inc., 1992.

[8] Widiasanti, Irika., \& Lenggogeni., Manajemen Konstruksi, PT Remaja Rosdakarya: Bandung, 2013.

[9] Karima, Mulyawati, N., Analisis Multiple Resource Leveling Menggunakan Metode Modified Minimum Moment Pada Pembangunan Pabrik PakanTernak Koperasi Agro Niaga Jabung, Skripsi: Briwijaya, 2017.

[10] Banjarnahor, Marali., Manajemen Proyek, Bahan Ajar, S1 Teknik Industri UMA: Medan, 2002.

[11] Mustarohmah, Siti., Metode Pelaksanaan Proyek, PT. Sarana Pembangunan Pantura, Tuban, Jawa Timur, 2016. 